\title{
Evidence-based vaccinology: The work of the Cochrane Vaccines Field
}

\author{
Tom Jefferson, Vittorio Demicheli, Mark Pratt
}

Cochrane Vaccines Field, Ministry of Defence, Keogh Barracks, Ash Vale, Hants, GU12 5RR

Correspondence to: Dr Jefferson.

Accepted for publication 22 July 1997
The volume of vaccine analytical literature is notable (the journal Vaccine alone having published 231 trials on different vaccines between 1983 and $1994^{1}$ ). However, to date little attention has been paid to summarising and evaluating its significance in the assessment of vaccine quality (defined as efficacy, effectiveness, efficiency, safety, and acceptability). Quality assessment is important as vaccines are a widely used preventive technology, vaccination programmes are mostly publicly funded, and decisions to immunise whole populations must be made on the best available evidence, especially if such practice is regulated by law. Additionally the current array of vaccines is likely to be augmented considerably in scope and variety by new vaccines imposing a resource burden on society. Such a burden, set against the backdrop of increased health care costs, will necessitate discrimination of funding of preventive programmes. Discrimination should be partly based on the best available evidence of vaccine effectiveness and safety, of the social burden of the target disease and of the ability of the vaccine to prevent that burden developing. $^{2}$

The Cochrane Vaccines Field (CVF) was founded to facilitate the gathering of evidence on vaccines and their effects (such as ability to prevent the target disease, short and long term

Table 1 Existing contributions of systematic reviews of vaccines by disease burden and effect. Knowledge gaps are left blank

\begin{tabular}{|c|c|c|c|c|c|c|c|}
\hline Vaccines available* & $\begin{array}{l}\text { Global } \\
\text { burden } \\
\text { (DALYs in } \\
\text { thousands) } t\end{array}$ & $\begin{array}{l}\text { Number of reports of } \\
\text { vaccine trials in } \\
\text { Cochrane Controlled } \\
\text { Trials Register } \neq\end{array}$ & $\begin{array}{l}\text { Cochrane Collaborative Review } \\
\text { GroupS }\end{array}$ & $\begin{array}{l}\text { Existing/currently } \\
\text { anticipated } \\
\text { review in } \\
\text { Cochrane } \\
\text { Database of } \\
\text { Systematic } \\
\text { Reviews } 9\end{array}$ & $\begin{array}{l}\text { Other systematic } \\
\text { review in Database of } \\
\text { Abstracts of Reviews } \\
\text { of Effectiveness }\end{array}$ & $\begin{array}{l}\text { Number of } \\
\text { economic } \\
\text { evaluations/ } \\
\text { studies } \star \star \star\end{array}$ & $\begin{array}{l}\text { Cost per } \\
\text { DALY } \\
\text { gained }\end{array}$ \\
\hline $\begin{array}{l}\text { Respiratory } \\
\text { infections }\end{array}$ & 130460 & & & & & & \\
\hline Influenza & & 125 & Ac resp infn & Yes (1) & Yes $(4)$ & 33 & \\
\hline Adenovirus & & 2 & Ac resp infn & No & No & & \\
\hline Pneumococcus & & 38 & Ac resp infn & Yes (1) & Yes (2) & 3 & \\
\hline Pertussis & & 124 & Ac resp infn & No & No & & \\
\hline Diphtheria & & 114 & Ac resp infn & No & No & & \\
\hline Diarrhoeal diseases & 99633 & & & & & & \\
\hline Rotavirus & & 69 & Infect dis & No & Yes $(1)$ & 1 & \\
\hline Shigella & & 4 & Infect dis & No & No & & \\
\hline Cholera & & 59 & Infect dis & Yes (2) & No & & \\
\hline Typhoid & & 21 & Infect dis & No & No & & \\
\hline Tuberculosis & 38426 & 28 & Infect dis & No & Yes (3) & & \\
\hline Measles & 36520 & 72 & Ac resp infn & No & Yes (1) & 3 & $\begin{array}{l}\$ 600 \\
\text { approx }\end{array}$ \\
\hline Malaria & 31706 & 31 & Infect dis & Yes $(1)$ & No & & \\
\hline Tetanus & 17517 & 113 & $\begin{array}{l}\text { Infect dis and pregnancy and } \\
\text { childbirth }\end{array}$ & No & No & & \\
\hline $\begin{array}{l}\text { Bacterial } \\
\quad \text { meningitides }\end{array}$ & 6242 & & & & & & \\
\hline $\mathrm{H}$ Influenza $\mathrm{b}$ & & 90 & Ac resp infn & No & Yes (1) & 6 & \\
\hline $\begin{array}{l}\text { Meningococcus } \\
\text { Other diseases }\end{array}$ & & 27 & Ac resp infn & Yes $(1)$ & No & & \\
\hline $\begin{array}{l}\text { Other diseases } \\
\text { Poliovirus }\end{array}$ & 3371 & 37 & Infect dis & No & No & & \\
\hline Hepatitis & 2136 & 366 & Hepato biliary & Yes (3) & Yes (3) & 149 & \\
\hline $\begin{array}{l}\text { Japanese } \\
\text { Encephalitis }\end{array}$ & 744 & 3 & Infect dis & No & No & 19 & \\
\hline Leprosy & 384 & 16 & Skin group & No & No & & \\
\hline Rabies & & 29 & Infect dis & No & No & 2 & \\
\hline Plague & & 0 & Infect dis & Yes (1) & No & & \\
\hline $\begin{array}{l}\text { Tick borne } \\
\text { encephalitis }\end{array}$ & & 3 & Infect dis & Yes $(1)$ & No & & \\
\hline Rubella & & 38 & Preg and childbirth & No & No & & \\
\hline Mumps & & 38 & Ac resp infn & No & No & & \\
\hline Varicella Zoster & & 24 & Infect dis & No & No & & \\
\hline Yellow Fever & & 6 & Infect dis & No & No & & \\
\hline Anthrax & & 0 & Infect dis & Yes $(1)$ & No & & \\
\hline
\end{tabular}

${ }^{\star}$ Salisbury DM, Begg NT, eds. 1996 Immunisation against infectious disease. London: Department of Health (UK), 1996. Bjorvatn B, ed. Vaccine. The European Commission COST/STD-3 initiative on European vaccine research, 1996: 14.

†Murray CJ, Lopez AD, ed. Global burden of disease. A comprehensive assessement of mortality and disability from diseases, injuries and risk factors in 1990 and projected to 2020. Washington: 1996. Harvard School of Public Health on behalf of the World Health Organization and the World Bank.

$\ddagger$ The Cochrane Controlled Trials Register (CCTR). Oxford: The Cochrane Library, Update Software Ltd.

SAbout the Cochrane Collaboration. Oxford: The Cochrane Library, Update Software Ltd.

IThe Cochrane Database of Systematic Reviews (CDSR). Oxford: The Cochrane Library, Update Software Ltd. (Figures in parentheses show the number of reviews in CDSR).

${ }^{\star}$ The Database of Abstracts of Reviews of Effectiveness (DARE). Oxford: The Cochrane Library, Update Software Ltd. (Figures in parentheses show the number of reviews in DARE).

$\star \star \star$ Database of vaccine studies held by the Cochrane Vaccines Field. 
safety and efficiency in making best use of scarce resources) into systematic reviews. Trials alone are unlikely to answer questions related to the long term effects of vaccines and the incidence of rare side effects (the mean length of study duration of 59 reports of randomised controlled trials and CCTs on hepatitis B vaccines was 270 days (median 420 days)). ${ }^{1}$ Inevitably important aspects of vaccine quality will have to be assessed also by the means of available observational studies, either of cohort or case-control design.

The economics of vaccinology suffer from several methodological problems, such as a variable quality of studies and an "inverse incidence law" whereby the higher the global impact of the target disease the lower the number of its economic evaluations. ${ }^{3}$ To increase knowledge on the economics of vaccines the CVF has promoted two systematic reviews of economic evaluations of vaccines (hepatitis B and influenza) and is developing possible methods to sum up economic information.
To assist the process of prioritisation a valid and generalisable measure of vaccine effect on public health would be desirable. Despite its limits the calculation of the burden of disease in DALYs (Disability Adjusted Life Years) seems a promising way foward. ${ }^{4}$ For this reason the available DALY data for preventable disease have been used in table 1, which summarises the available knowledge on the effectiveness and economics of vaccines and current gaps in evidence-based vaccinology.

The authors gratefully acknowledge the help and inspiration received from Iain Chalmers.

1 Jefferson TO, Jefferson VM. The quest for trials on the efficacy of human vaccines. Results of the handsearch of Vaccine. Vaccine 1996;14:461-4.

2 Jefferson $\mathrm{T} O$. New and not so new vaccines. BMF 1996;313:768.

3 Demicheli V, Jefferson T O. Economic aspects of vaccination.Vaccine 1996;14:941-3.

4 Murray CJL, Lopez AD, eds. The global burden of disease. The global burden of disease: a comprehensive assessment of mortality and disability from diseases, injuries and risk factors in 1990 and projected to 2020. Cambridge: Harvard University 